\title{
The Causes of Work Incident According to Work Shift System on Operator of a Woven Bag Company, Sidoarjo
}

\author{
Penyebab Insiden Kerja Berdasarkan Sistem Shift Kerja pada Operator di \\ Perusahaan Woven Bag, Sidoarjo
}

\author{
Shintia Yunita Arini \\ Department of Occupational Safety and Health, Faculty of Public Health Universitas Airlangga \\ Campus C Mulyorejo, Surabaya, East Java 60115
}

\begin{abstract}
Introduction: In the recent years, woven bag companies have taken a step forward from traditional labor intensive work practices to technological assistance which is operated by workers. Nevertheless, the increased production capability and capacity with assistance of the machineries has been known to cause significant Occupational Safety and Health concerns as having been reported in various previous studies. Therefore, this research aimed to determine the causes of work incident according to work shift system on operator of a woven bag company. Methods: This research was an analytical observational study with cross-sectional design. There was a total of 67 operators being the population of this study, 53 of whom were recruited as respondents using simple random sampling. The instruments that were used in this research were questionnaires about individual characterization, perception of work environment and work incidents. Variable testing was performed using contingency coefficient. Results: There was a relationship between the complaint towards the noise and the work incident in the morning and afternoon shift. Based on the measurement of the noise, the value was high in the morning of 100dBA, while in the afternoon the value was $91 \mathrm{dBA}$ and at night the value was $92 \mathrm{dBA}$. For the variable of dry temperature, there was a relationship between the complaint towards the dry temperature and the work incident, which showed that in the morning, the dry temperature was $33 \cdot 1^{\circ} \mathrm{C}$. Conclusion: High noise and dry temperature exposure value had a relationship with the work incident on the operators of a Woven Bag Company.
\end{abstract}

Keywords: dry temperature, noise, shift worker, work incident

\begin{abstract}
ABSTRAK
Pendahuluan: Beberapa tahun terakhir, Perusahaan Karung telah melakukan inovasi dibidang teknologi sehingga seluruh pekerjaannya menggunakan bantuan mesin yang kemudian dioperasikan oleh operator. Berdasarkan aktivitas pekerjaan yang menggunakan bantuan mesin tersebut, menghasilkan paparan bising dan suhu kering yang cukup tinggi. Sementara operator bekerja dengan sistem rotasi shift dan berdasarkan laporan perusahaan, angka insiden kecelakaan kerja yang dialami operator cukup tinggi. Sehingga, penelitian ini bertujuan untuk mengetahui penyebab insiden kerja berdasarkan sistem shift kerja pada operator di perusahaan woven bag. Metode: Penelitian ini merupakan penelitian observasional analitik dengan pendekatan cross sectional. Populasi penelitian ini berjumlah 67 operator kemudian sample diambil menggunakan teknik simple random sampling dan didapatkan sampel sejumlah 53 operator. Alat ukur yang digunakan di penelitian ini antara lain kuesioner terkait karakteristik individu, persepsi terkait paparan lingkungan kerja dan kejadian kecelakaan kerja. Uji variable yang digunakan adalah contingency coefficient. Hasil: Terdapat hubungan antara keluhan terhadap kebisingan dengan insiden kecelakaan kerja pada saat shift pagi dan sore, berdasarkan pengukuran kebisingan menunjukkan angka yang cukup tinggi yaitu pada pagi 100dBA, sore 91 dBA dan malam 92dBA. Pada variable suhu kering terdapat hubungan antara keluhan terhadap suhu kering dengan insiden kecelakaan kerja pada saat shift pagi, berdasarkan pengukuran suhu kering yang menunjukkan angka pada saat shift pagi, suhu keringnya sebesar $33.1^{\circ} \mathrm{C}$. Simpulan: Paparan bising dan suhu kering yang tinggi memiliki hubungan dengan terjadinya insiden kecelakaan kerja pada operator di Perusahaan Karung.
\end{abstract}

Kata kunci: kecelakaan kerja, kebisingan, pekerja shift, suhu kering

Corresponding Author:

Shintia Yunita Arini

Email: shintia.arini@fkm.unair.ac.id

Telephone: +6282233031117

(C2021 IJOSH All right reserved. Open access under CC BY NC-SA license doi:10.20473/ijosh.v10i2.2021.233-239

Received May 24, 2020, received in revised form July 14, 2021, Accepted July 24, 2021, Published: August 2021 


\section{INTRODUCTION}

The development of the industry sector, particularly manufacture industry, in Indonesia has obtained special attention from the government due to the entry of free market in this country. This certainly makes many companies eventually change their human labor to machine as one of the utilizations of technological advancement. The positive effect is that the production time becomes efficient, the production target is easier to achieve and the manual handling activities can be minimized. However, this also gives a negative effect as the workers' activity is changed into a machine operator, without supported by good Occupational Safety and Health commitment from the company, so it can cause various work incident risks since the workers directly contact with various machine tools.

Work incident is an unplanned and uncontrolled incident caused by people's action or reaction, materials or objects which can cause injury or other possibilities which can harm humans, and a workplace and its environment (Suma'mur, 2013). Based on the data released by the Social Insurance Administration Organization of Manpower (BPJS Ketenagakerjaan), there were 157,000 work incident cases in $2018,1.6 \%$ of which $(4.678$ cases) caused death and 3\% of which (2.439 cases) caused disability (BPJS Ketenagakerjaan, 2019). There is also a possibility that the unreported work incident number is higher than the number of cases reported.

A woven Bag Company in Sidoarjo has been innovating, particularly in technological aspect, in which all types of product processing are done with the assistance of a machine, so the presence of the workers is only as the operators. Based on the report given by a Woven Bag Company in Sidoarjo, there is always a work incident almost every month such as hands pierced by a sharp object or hands strangulated by a machine. Several cases even reported the workers' finger to be amputated (Arini, 2018). The Woven Bag Company in Sidoarjo operates for 24 hours. All operators work through shift rotation without looking at the age and gender. They work through a rotation rhythm in which the pattern of their work is night shift-time off-afternoon shift-time off-morning shift-time off, and it will reoccur continuously. Such a work shift pattern definitely causes a higher risk of work incidents since work incidents are mostly found on workers who work through shift systems (Salminen, 2014; Stimpfel, Brewer and Kovner, 2015).
Physical factor exposure in the woven bag company in Sidoarjo is also not quite good and becomes one of the main problems in the company. Based on the measurement that has been done in this company, noise and dry temperature exposures exceeded the threshold value regulated by the Regulation of the Minister of Manpower Number 13 of 2011 concerning the Threshold Value of Physical Factor and Chemical factor in Workplace (Ministry of Manpower and Transmigration, 2011). The exposure obtained by the workers which exceeds the threshold value will certainly trigger NIHL for the noise exposure and triggers the heat stress for the dry temperature exposure. Workers, therefore, mustregularly be given medical checkup facilities because health problems will make the workers' performance decrease and cause them to act unsafely (Hakro and Jinshan, 2019). Various kinds of problems in the workplace increase the risk of work incidents for workers with the shift system (Rahmani et al.,2013) because the physical environmental conditions that do not match the threshold values make the workers' conditions more unsafe and uncomfortable, so it is easy for workers to lose focus and eventually experience a work accident (Verma and Chaudhari, 2017).

Based on the theory, initial research, and observation results in the company that have been explained above, research regarding the causes of work incident according to work shift system on operator of a woven bag company in Sidoarjo was conducted.

\section{METHODS}

This research used a quantitative approach method, and based on the time this research was conducted it was categorized as cross sectional. The data collection was carried out in April 2018. The research location was in a Woven Bag Company in Sidoarjo, and the respondents who were given prior inclusion criteria were the workers who had experienced work incidents in the last 6 months. Thus, the total population obtained after the inclusion in the Division Circular Room (one of the divisions which exist in a Woven Bag Company) was as many as 67 operators, who were then sampled through simple random sampling obtaining 53 operators. The research variables were individual characteristics (age, gender, knowledge of Occupational Safety and Health), subjective complaint towards the perception of work environmental exposure (noise 
perception, dry temperature perception), and work incident. The research instrument was made by the research team without a validity and reliability test because the scale of the questionnaire was nominal. The data were then analyzed using a chi-square contingency coefficient test since the lowest variable had a nominal scale. Noise measurement was also performed using a sound level meter, while dry temperature was measured using a Heat Stress Apparatus of Quest Temp 36, which had already been calibrated to compare the results from the perception of work environmental exposure and the real condition in the research place.

This study has been approved by the Ethics Committee of the Faculty of Public Health Universitas Airlangga. The registration number of ethical clearance is 58-KEPK 2018.

\section{RESULTS}

Based on Table 1, it is shown that workers who mostly experienced a work incident was from the age group of $>35$ years old, whether it was in the morning shift $(64 \%)$, afternoon shift $(58 \%)$ or night shift (68\%). Moreover, the variable of gender showed that workers who mostly experienced a work incident was females whether it was in the morning shift (61\%), afternoon shift (58.5\%) or night shift $(70.7 \%)$. Meanwhile, the variable of knowledge of occupational safety and health showed that workers who mostly experienced a work incident were workers who had bad occupational safety and health knowledge level, whether it was in the morning shift $(62.9 \%)$, afternoon shift $(65.7 \%)$ or night shift (65.7\%).
Based on Table 2 about the variable of subjective complaint on the noise, it is shown that workers who mostly experienced a work incident were the workers who worked in the Circular room, in which the percentage of the workers who were disturbed with the noise in the morning shift was $78.6 \%$, in the afternoon shift was $75 \%$ and in the night shift was $64.5 \%$. Moreover, the statistical test obtained results that the p-value of the workers in the morning shift was 0.021 with the correlation strength of 0.335 , the p-value of workers in the afternoon shift was 0.021 with the correlation strength of 0.334 , while p-value of workers in the night shift was 0.488 with the correlation strength of 0.136 .

Based on Table 3 about the variable of subjective complaint on the dry temperature, the workers who mostly experienced a work incident were the workers who worked in the division of Circular room, in which the percentage of the workers who were in the morning shift was $65.8 \%$, workers who were in the afternoon shift was $75 \%$ and workers who were in the night shift was $73.5 \%$. The statistical test obtained results that the p-value of workers in the morning shift was 0.597 with the correlation strength of 0.115 , the p-value of workers in the afternoon shift was 0.021 with the correlation strength of 0.334 , while the p-value of workers in the night shift was 0.634 with the correlation strength of 0.108 .

Based on Table 4, it is shown that the results for the threshold value of the noise and dry temperature in morning, afternoon and night shift exceeded the threshold value determined by the government.

Table 1. Cross Tabulation of Individual Characteristics by Work Incidents in the Morning, Afternoon and Night Shift in a Woven Bag Company Sidoarjo, 2018

\begin{tabular}{|c|c|c|c|c|c|c|c|c|c|c|c|c|}
\hline \multirow{4}{*}{ Variable } & \multicolumn{12}{|c|}{ Work Incidents Occurred } \\
\hline & \multicolumn{4}{|c|}{ Morning Shift } & \multicolumn{4}{|c|}{ Afternoon Shift } & \multicolumn{4}{|c|}{ Night Shift } \\
\hline & \multicolumn{2}{|c|}{ Yes } & \multicolumn{2}{|c|}{ No } & \multicolumn{2}{|c|}{ Yes } & \multicolumn{2}{|c|}{ No } & \multicolumn{2}{|c|}{ Yes } & \multicolumn{2}{|c|}{ No } \\
\hline & $\mathbf{n}$ & $\%$ & n & $\%$ & n & $\%$ & $\mathbf{n}$ & $\%$ & $\mathbf{n}$ & $\%$ & $\mathbf{n}$ & $\%$ \\
\hline \multicolumn{13}{|c|}{ Age } \\
\hline$\leq 35$ years old & 1 & 33.3 & 2 & 66.7 & 2 & 66.7 & 1 & 33.3 & 3 & 100 & 0 & 0 \\
\hline$>35$ years old & 32 & 64.0 & 18 & 36.0 & 29 & 58.0 & 21 & 42.0 & 34 & 68.0 & 16 & 32.0 \\
\hline \multicolumn{13}{|c|}{ Sex } \\
\hline Male & 8 & 66.7 & 4 & 33.3 & 7 & 58.3 & 5 & 41,7 & 8 & 66.7 & 4 & 33.3 \\
\hline Female & 25 & 61.0 & 16 & 41.0 & 24 & 58.5 & 17 & 41.5 & 29 & 70.7 & 12 & 29.3 \\
\hline \multicolumn{13}{|c|}{ Knowledge of Occupational Health and Safety } \\
\hline Good & 11 & 61.1 & 7 & 38.9 & 8 & 44.4 & 10 & 55,6 & 14 & 77.8 & 4 & 22.2 \\
\hline Poor & 22 & 62.9 & 13 & 37.1 & 23 & 65.7 & 12 & 34.3 & 23 & 65.7 & 12 & 34.3 \\
\hline
\end{tabular}


Table 2. Correlation Between the Perception of Noise and Work Incidents in the Morning, Afternoon and Night Shift in a Woven Bag Company Sidoarjo, 2018

\begin{tabular}{|c|c|c|c|c|c|c|c|c|}
\hline \multirow{3}{*}{$\begin{array}{c}\text { Perception of } \\
\text { Noise }\end{array}$} & \multicolumn{4}{|c|}{ Work Incident } & \multirow{2}{*}{\multicolumn{2}{|c|}{ Total }} & \multirow{3}{*}{ p-value } & \multirow{3}{*}{$\mathbf{r}$} \\
\hline & \multicolumn{2}{|c|}{ Yes } & \multicolumn{2}{|c|}{ No } & & & & \\
\hline & $\mathbf{n}$ & $\%$ & $\mathbf{n}$ & $\%$ & $\mathbf{N}$ & $\%$ & & \\
\hline \multicolumn{9}{|c|}{ Morning Shift } \\
\hline Disturbed & 22 & 78.6 & 6 & 21.4 & 28 & 100 & \multirow{2}{*}{0.021} & \multirow{2}{*}{0.335} \\
\hline Not Disturbed & 11 & 44.0 & 14 & 56.0 & 25 & 100 & & \\
\hline \multicolumn{9}{|c|}{ Afternoon Shift } \\
\hline Disturbed & 21 & 75.0 & 7 & 25.0 & 28 & 100 & \multirow{2}{*}{0.021} & \multirow{2}{*}{0.334} \\
\hline Not Disturbed & 10 & 40.0 & 15 & 60.0 & 25 & 100 & & \\
\hline \multicolumn{9}{|c|}{ Night Shift } \\
\hline Disturbed & 20 & 64.5 & 11 & 35.5 & 31 & 100 & \multirow{2}{*}{0.488} & \multirow{2}{*}{0.136} \\
\hline Not Disturbed & 17 & 77.3 & 5 & 22.7 & 22 & 100 & & \\
\hline
\end{tabular}

Table 3. Correlation Between the Perception of Dry Temperature and Work Incidents in the Morning, Afternoon and Night Shift in a Woven Bag Company Sidoarjo, 2018

\begin{tabular}{|c|c|c|c|c|c|c|c|c|}
\hline \multirow{3}{*}{$\begin{array}{l}\text { Perception of Dry } \\
\text { Temperature }\end{array}$} & \multicolumn{4}{|c|}{ Work Incident } & \multirow{2}{*}{\multicolumn{2}{|c|}{ Total }} & \multirow{3}{*}{ p-value } & \multirow{3}{*}{$\mathbf{r}$} \\
\hline & \multicolumn{2}{|c|}{ Yes } & \multicolumn{2}{|c|}{ No } & & & & \\
\hline & n & $\%$ & $\mathbf{n}$ & $\%$ & $\mathbf{N}$ & $\%$ & & \\
\hline \multicolumn{9}{|c|}{ Morning Shift } \\
\hline Disturbed & 25 & 65.8 & 13 & 34.2 & 38 & 100 & \multirow{2}{*}{0.97} & \multirow{2}{*}{0.115} \\
\hline Not Disturbed & 8 & 53.3 & 7 & 46.7 & 15 & 100 & & \\
\hline \multicolumn{9}{|c|}{ Afternoon Shift } \\
\hline Disturbed & 21 & 75.0 & 7 & 25.0 & 28 & 100 & \multirow{2}{*}{0.021} & \multirow{2}{*}{0.334} \\
\hline Not Disturbed & 10 & 40.0 & 15 & 60.0 & 25 & 100 & & \\
\hline \multicolumn{9}{|c|}{ Night Shift } \\
\hline Disturbed & 25 & 73.5 & 9 & 26.5 & 34 & 100 & \multirow{2}{*}{0.634} & \multirow{2}{*}{0.108} \\
\hline Not Disturbed & 12 & 63.2 & 7 & 36.8 & 19 & 100 & & \\
\hline
\end{tabular}

Table 4. The Measurement Results of Noise and Dry Temperature in the Morning, Afternoon and Night Shift in a Woven Bag Company Sidoarjo, 2018

\begin{tabular}{cccc}
\hline Measurement Result & Morning Shift & Afternoon Shift & Night Shift \\
\hline Noise & $100 \mathrm{dBA}$ & $91 \mathrm{dBA}$ & $92 \mathrm{dBA}$ \\
Dry Temperature & $34.7^{\circ} \mathrm{C}$ & $33.8^{\circ} \mathrm{C}$ & $28.1^{\circ} \mathrm{C}$ \\
\hline
\end{tabular}

\section{DISCUSSION}

According to the cross-tabulation on individual characteristics for age variable, it was shown that the operators were mostly aged $>35$ years old. In fact, optimal physical ability of someone can be achieved at the age between 25 and 35 years old. After 35 years old, a person will experience a decrease in a particular functional capacity needed by the body to do a certain action (Suma'mur, 2013). In addition, age also significantly affects the incident at work for workers aged $>35$ years old (Lombardi et al., 2014). Several studies have stated that workers $>35$ years old experienced several work incidents that could have actually been prevented (Abukhashabah, Summan and Balkhyour, 2020). The age inequality among the operators is caused by the worker regeneration process in the company which is not done regularly, in which the workers need to wait until another worker is in retirement. Management of workers' age arrangements is very important because for workloads that require physical strength it will be better if they are given to workers with relatively young ages (Dimovski et al., 2019).

In relation to the gender variable based on the cross-tabulation table, it was shown that workers 
who mostly experienced work incidents were the female operators. Similar research stated that female workers who worked on a shift system had a higher risk of experiencing work incidents (Nielsen et al., 2019). Females have a maximal oxygen volume of $15-30 \%$ lower than males. Such a condition causes females to have high fat percentage and low hemoglobin level, making females weaker than males in terms of physical work (Tarwaka, 2004). Female workers indeed tend to experience work incidents more often (Lombardi et al., 2014). Most of the workers, accounting for more than $70 \%$ of the total workers in this company, were females. However, through the rotating shift system, the female workers were also obliged to work in the afternoon shift (work finished at 23.00), and in the night shift (work started at 23.00 and finished at 07.00). Natural physical condition of females indeed tends to be weaker than that of males. In addition, the high demand in working also adds the risk for female operators to experience work incidents (Osca and López-Araújo, 2020). Moreover, in relation to the variable of the knowledge of occupational safety and health through the cross tabulation, it was shown that workers who mostly experienced work incidents were the operators who were in the bad category of occupational safety and health knowledge. A person's educational level is important to be paid attention to in order to increase the awareness of the importance of occupational safety and health (Gedik and Korkut, 2011). Knowledge of occupational safety and health affects the effort of preventing work incident (Esaiyas, Sanbata and Mekonnen, 2018). Workers with good knowledge can prevent themselves from experiencing work incidents. A good perception of hazard risks in the workplace can also make workers care more about their safety (Oah, Na and Moon, 2018). Meanwhile, workers who have less knowledge about occupational safety and health are more likely to be at risk of engaging in unsafe action (Asady et al., 2018).

In addition, based on the variable of work environment exposure factor, the noise and work incident had a relationship with workers who worked in the morning and afternoon shifts since the noise experienced was not only from the machine or tools used for the work, but also from various other factors including lifting work activities using forklifts, which were mostly done in the morning and afternoon. Besides, the noise also came from the road due to the high traffic in the morning and afternoon shift, so it caused the increase of noise trigger factor for the workers who worked in the morning and afternoon shift. According to the measurement of noise using a sound level meter, it was shown that the noise value in the morning, afternoon and night shift exceeded the threshold value determined by the government, which must be no more than $85 \mathrm{dBa}$ (the noise value in the morning was $100 \mathrm{dBA}$, in the afternoon was $91 \mathrm{dBA}$ and at night was $92 \mathrm{dBA}$ ) with the working hours of 8 hours/day or 40 hours/week (Salminen, 2014).

The increase in the noise intensity can disturb concentration and cause distraction, so the workers cannot focus on what they are doing (Suma'mur, 2013). Thus, it can lead to work incidents or loss of experience (Tarwaka, 2004). Another problem with the noise in the company is that teh workers do not use personal protective equipment at all because most of them had worked for long periods of work and they were used to the annoying sound. This feeling of being used to or having adapted actually shows that they have indeed experienced a decrease in their hearing aid (Thepaksorn et al., 2018). Workers exposed to high noise will experience hearing disorders, which becomes one of the increasing factors of work incidents (Buksh et al., 2018).

Meanwhile, for the variable of work environment exposure, dry temperature and work incidents were related only to the afternoon shift since the work started from 15.00 until 23.00 in which the workers would experience two significant temperature differences. It makes the workers' body have to adapt to the temperature change, which certainly quite disturbs the workers. Moreover, based on the dry temperature measurement results using the Heat Stress Apparatus of Quest Tipe Quest Temp 36, the dry temperature in the morning, afternoon and night shift exceeded the threshold value determined by the government, which is in the range of $23^{\circ} \mathrm{C}$ to $28^{\circ} \mathrm{C}$ (Ministry of Health of the Republic of Indonesia, 2016).

Work environmental condition especially the dry temperature in a company is indeed very high since there is only a blower in the room, in which the blower function is inputting the air from the outside to the inside. Thus, when the temperature outside is high, then it will make the high temperature in the room worse. In addition, the high temperature also comes from the activities of hundreds of machines in the working space. The high temperature in the work environment can cause work incidents (Kim et al., 2017). Workers exposed to high temperature will 
emit a lot of sweat fluid as a process of adaptation, and loss of fluid, if it is not balanced with a lot of water and sodium intake, will make workers easily lose concentration (Tamura and Tanaka ,2016). As a consequence, workers will feel tiredness and sleepiness as well as heat exhaustion, which can decrease stability and increase the number of work failures, so the possibility of the workers doing unsafe actions increases (Tarwaka, 2004).

\section{CONCLUSION}

The results of research conducted in a Woven Bag Company in Sidoarjo showed that based on age, workers who mostly experienced a work incident were workers who were aged more than 35 years old. Moreover, based on gender, workers who mostly experienced a work incident were female operators, while based on the knowledge of occupational safety and health, workers who mostly experienced work incidents were the operators who had a lack of knowledge of occupational safety and health. Meanwhile, for the noise exposure based on the measurement, the noise level in the morning, afternoon and night shift exceeded the threshold value, and based on the subjective complain the correlation was only noted in the morning and afternoon shift. In addition, for the dry temperature exposure, it was shown that based on the measurement, the dry temperature exceeded the threshold value of comfortable temperature in the workplace, which happenned only in the afternoon shift. The recommendations of this study are the Woven Bag Company needs to re-arrange the work shift systems for the woman workers so they can only work in the morning and afternoon shift, the company also needs to install some exhaust fans to expedite air circulation so the heat in that room can be reduced, and the company needs to provide the workers earplugs to reduce the noise.

\section{ACKNOWLEDGMENTS}

The authors would like to thank all the operators and the management of Woven Bag Company Sidoarjo for being very responsive and cooperative during the research. We would also thank the lecturers in the Department of Occupational Health and Safety, Faculty of Public Health, Universitas Airlangga for giving advices during the accomplishment of this article.

\section{REFERENCES}

Abukhashabah, E., Summan, A. and Balkhyour, M. (2020) 'Occupational Accidents and Injuries in Construction Industry in Jeddah City', Saudi Journal of Biological Sciences, 27(8), pp. 1993-1998.

Arini, S. Y. (2018) Faktor Penyebab Incident Kecelakaan Kerja Pada Pekerja Shift Di PT. Kerta Rajasa Raya Sidoarjo. Thesis. Surabaya: Faculty of Public Health, Universitas Airlangga.

Asady, H. et al. (2018) 'Risk Factors of Fatal Occupational Accidents in Iran', Annals of Occupational and Environmental Medicined, 30(1), pp. 1-7.

BPJS Ketenagakerjaan (2019) 'Angka Kecelakaan Kerja Cenderung Meningkat, BPJS Ketenagakerjaan Bayar Santunan Rp1,2 Triliun', Jakarta: BPJS Ketenagakerjaan.

Buksh, N. et al. (2018) 'Occupational Noise Exposure and its Impact on Worker's Health and Activities', International Journal of Public Health and Clinical Sciences, 5(2), pp. 180-195.

Dimovski, V. et al. (2019) 'Age Management of Industrial Workers based on the Multiple Decrement Modelling', Procedia Manufacturing, 39(2019), pp. 1455-1463.

Esaiyas, A., Sanbata, H. and Mekonnen, Y. (2018) 'Occupational Health and Safety Related Knowledge, Attitude and Practice among Wood and Metal Workers in Hawassa, Ethiopia', Annual Research \& Review in Biology, 22(6), pp. 1-9.

Gedik, T. and Korkut, D. S. (2011) 'A Research on Work Accidents in Forest Products Industry in Duzce', International Journal of Physical Sciences, 6(30), pp. 7065-7072.

Hakro, S. and Jinshan, L. (2019) 'Workplace Employees' Annual Physical Checkup and During Hire on the Job to Increase Health-care Awareness Perception to Prevent Disease Risk: A Work for Policy-Implementable Option Globally', Safety and Health at Work, 10(2), pp. 132-140.

Kim, K. W. et al. (2017) 'Safety Climate and Occupational Stress According to Occupational Accidents Experience and Employment Type in Shipbuilding Industry of Korea', Safety and Health at Work, 8(3), pp. 290-295.

Lombardi, D. A. et al. (2014) 'The Effects of Rest Breaks, Work Shift Start Time, and Sleep on the Onset of Severe Injury among Workers in the People's Republic of China', Scandinavian Journal of Work, Environment and Health, 40(2), pp. $146-155$. 
Ministry of Health of the Republic of Indonesia (2016) Number 48 Office Occupational Safety and Health Standards. Jakarta: Ministry of Health of the Republik of Indonesia.

Ministry of Manpower and Transmigration (2011) Regulation Number 13 of 2011 on Threshold Limit Value of Physical Factors and Chemical Factors in a Workplace. Jakarta: Ministry of Manpower and Transmigration.

Nielsen, H. B. et al. (2019) 'Shift Work and Risk of Occupational, Transport and Leisure-time Injury. A Register-based Case-crossover Study of Danish Hospital Workers', Safety Science, 120(May), pp. 728-734.

Oah, S., Na, R. and Moon, K. (2018) 'The Influence of Safety Climate, Safety Leadership, Workload, and Accident Experiences on Risk Perception: A Study of Korean Manufacturing Workers', Safety and Health at Work, 9(4), pp. 427-433.

Osca, A. and López-Araújo, B. (2020) 'Work Stress, Personality and Occupational Accidents: Should we Expect Differences between Men and Women?', Safety Science, 124(June), p. 104582.

Rahmani, A. et al. (2013) 'Descriptive Study of Occupational Accidents and Their Causes among Electricity Distribution Company Workers at an Eight-Year Period in Iran', Safety and Health at Work, 4(3), pp. 160-165.
Salminen, S. (2014) 'Shift Work and Extended Working Hours as Risk Factors for Occupational Injury', The Ergonomics Open Journal, 3(1), pp. 14-18.

Stimpfel, A. W., Brewer, C. S. and Kovner, C. T. (2015) 'Scheduling and Shift Work Characteristics Associated with Risk for Occupational Injury in Newly Licensed Registered Nurses: An Observational Study', International Journal of Nursing Studies, 52(11), pp. 1686-1693.

Suma'mur (2013) Higiene Perusahaan Dan Kesehatan Kerja (Hiperkes). Jakarta: Sagung Seto.

Tamura, N. and Tanaka, T. (2016) 'Japan's Recent Tendencies of Accidents in Building Facilities and Workers' Accidents in the Environment of Extreme Temperature', Procedia Engineering, 146(2016), pp. 278-287.

Tarwaka (2004) Ergonomi untuk Keselamatan, Kesehatan Kerja dan Produktivitas. 1st edn. Surakarta: UNIBA PRESS.

Thepaksorn, P. et al. (2018) 'Relationship Between Noise-Related Risk Perception, Knowledge, and the Use of Hearing Protection Devices Among Para Rubber Wood Sawmill Workers', Safety and Health at Work, 9(1), pp. 25-29.

Verma, S. and Chaudhari, S. (2017) 'Safety of Workers in Indian Mines: Study, Analysis, and Prediction', Safety and Health at Work, 8(3), pp. 267-275. 